\title{
Bartter syndrome-like phenotype in a patient with diabetes: a case report
}

\author{
Chamara Dalugama*, Manoji Pathirage and S. A. M. Kularatne
}

\begin{abstract}
Background: Bartter's syndrome is a rare genetic tubulopathy affecting the loop of Henle leading to salt wasting. It is commonly seen in utero or in early neonatal period. Rare cases of acquired Bartter's syndrome are reported in association with infections like tuberculosis, granulomatous conditions like sarcoidosis, autoimmune diseases, and drugs. The mainstay of management includes potassium, calcium, and magnesium supplementation.

Case presentation: We report the case of a 62-year-old Sri Lankan Sinhalese man with diabetes and hypertension presenting with generalized weakness with clinical evidence of proximal myopathy. He was severely hypokalemic with high urinary potassium excretion and hypochloremic metabolic alkalosis. He poorly responded to intravenously administered potassium supplements. A diagnosis of idiopathic Bartter-like phenotype was made. He responded well to spironolactone and indomethacin.
\end{abstract}

Conclusions: Patients presenting with body weakness need serum potassium estimation. Acquired Bartter's syndrome although rare, should be ruled out in those with hypokalemia and metabolic alkalosis with increased urinary potassium loss with poor response to potassium replacement.

Keywords: Hypokalemia, Metabolic alkalosis, Bartter's syndrome, Acquired, Idiopathic

\section{Background}

Bartter's syndrome (BS) is a rare genetic condition described by Bartter and coworkers in 1962. It is a tubulopathy affecting the thick ascending limb of loop of Henle $(\mathrm{LOH})$ leading to salt wasting. It is characterized by hypokalemia, hypocalcemia, hypercalciuria, metabolic alkalosis, hyperreninemic hyperaldosteronism, and a normal blood pressure [1-4]. It is commonly seen in the prenatal and neonatal period. Very few cases of acquired BS are described in the literature; they are commonly associated with tuberculosis, autoimmune conditions, sarcoidosis, or following administration of drugs such as aminoglycosides [5-12]. We report a case of idiopathic BS-like phenotype in a man with diabetes.

\section{Case presentation}

A 62-year-old Sri Lankan Sinhalese man from the North Central Province of Sri Lanka presented with generalized malaise and body weakness. He had type 2 diabetes and had been on Mixtard (human insulin) for 10 years. He

\footnotetext{
* Correspondence: chamaradalugama@yahoo.com

Department of Medicine, University of Peradeniya, Peradeniya, Sri Lanka
}

had been hypertensive for 5 years and was on losartan potassium. His anti-hypertensive drugs were withheld 2 months previously because he had low-normal blood pressure. He described proximal muscle weakness of the body of 1 month's duration with difficulty in getting up from a squatting position and raising his hands above his head. He noticed polyuria and nocturia with recent worsening of glycemic control. There was no history of fever, vomiting, diarrhea, or any drug abuse prior to the onset of the symptoms. He denied a suggestive family history of diabetes mellitus, hypertension, or renal disease.

On examination, he was conscious and rational. His blood pressure was $110 / 64 \mathrm{~mm} \mathrm{Hg}$ and his pulse was $76 /$ minute. The rest of the cardiovascular system and respiratory system examination was normal. His abdomen was soft and non-tender. A neurological examination revealed normal higher functions and cranial nerves. A motor system examination showed hypotonia of all four limbs and a power of 4/5 in both lower limbs and 5/5 in both upper limbs. All reflexes were present, but diminished. His plantar reflex was bilaterally unresponsive. There was no sensory or autonomic involvement.

(c) The Author(s). 2018 Open Access This article is distributed under the terms of the Creative Commons Attribution 4.0 International License (http://creativecommons.org/licenses/by/4.0/), which permits unrestricted use, distribution, and reproduction in any medium, provided you give appropriate credit to the original author(s) and the source, provide a link to the Creative Commons license, and indicate if changes were made. The Creative Commons Public Domain Dedication waiver (http://creativecommons.org/publicdomain/zero/1.0/) applies to the data made available in this article, unless otherwise stated. 
Initial blood investigations showed sodium ion $(\mathrm{Na}+) 146 \mathrm{mEq} / \mathrm{L}$, potassium ion $(\mathrm{K}+) 1.95 \mathrm{mEq} / \mathrm{L}$, urea $4.3 \mathrm{mmol} / \mathrm{L}$, creatinine $0.7 \mathrm{mg} / \mathrm{dl}$, and random blood glucose $300 \mathrm{mg} / \mathrm{dl}$. His hemoglobin was $13.2 \mathrm{~g} / \mathrm{dL}$ with white count of $5.7 \times 10^{6}$ and platelets $240 \times 10^{6}$. Transaminases were normal. His serum albumin was $34 \mathrm{~g} / \mathrm{L}$. Severe hypokalemia was confirmed in the repeat blood sample. Arterial blood gas revealed severe metabolic alkalosis with $\mathrm{pH}$ of 7.6, partial pressure of carbon dioxide $\left(\mathrm{CO}_{2}\right)$ of $41 \mathrm{mmHg}$, and bicarbonate of $40.3 \mathrm{mmol} / \mathrm{L}$.

Further investigations revealed the following (Table 1). The results of an X-ray of his kidney-ureter-bladder and an ultrasound scan of his kidneys were normal with no evidence of nephrocalcinosis.

He was treated aggressively with intravenously administered potassium chloride, and calcium and magnesium supplements. But he was noted to have persistent hypokalemia with pottasium wasting in urine. Spironolactone was added to the treatment regime. On day 4 while receiving potassium chloride and spironolactone, his serum potassium was $2.6 \mathrm{mmol} / \mathrm{L}$. In this clinical context BS was suspected in our patient. Unfortunately, he could not afford plasma rennin and serum aldosterone levels. He was started on indomethacin $50 \mathrm{mg}$ thrice a day. On day 7 he was noted to have a marked improvement in proximal muscle weakness and his serum potassium reached $3 \mathrm{mmol} / \mathrm{L}$; with the correction of potassium, our patient's glycemic controlled improved. He was discharged with the advice of liberal salt intake, $\mathrm{K}+$ and magnesium cation $(\mathrm{Mg} 2+)$ supplements, spironolactone, and indomethacin. He is currently doing well with low normal potassium value with the above treatment.

\section{Discussion}

$\mathrm{BS}$ is a rare autosomal recessive condition first described by Bartter and his coworkers in 1962 [1]. BS results from mutations affecting any of the five ion transport proteins in the thick ascending $\mathrm{LOH}$, giving a clinical picture of salt wasting and hypokalemic metabolic alkalosis. In a

Table 1 Investigation findings of the patient

\begin{tabular}{lll}
\hline Serum calcium & $1.81 \mathrm{mmol} / \mathrm{L}$ & $(2.2-2.6)$ \\
Serum chloride & $93 \mathrm{mmol} / \mathrm{L}$ & $(102-109)$ \\
Serum magnesium & $0.73 \mathrm{mmol} / \mathrm{L}$ & $(0.73-1.06)$ \\
Serum osmolality & $282 \mathrm{mOsmol} / \mathrm{kg}$ & $(275-295)$ \\
Urine potassium & $30 \mathrm{mmol} / \mathrm{L}$ & $<25$ \\
Urine PH & 7.2 & \\
Urine calcium creatinine ratio & 0.47 & \\
Thyroid-stimulating hormone & $1.5 \mathrm{u} / \mathrm{L}$ & $(0.4-5.0)$ \\
\hline
\end{tabular}

report from the Framingham Heart Study, the prevalence of BS was 1 in 1,000,000 [2].

Biochemical abnormalities include hypokalemia, hyponatremia, mild hypomagnesemia, hypocalcemia, hypochloremic metabolic alkalosis, and reduced urine concentrating ability with increased urinary excretion of calcium and prostaglandins. Patients tend to have normal or low blood pressure. Nephrocalcinosis is a known association with long-standing BS. Plasma rennin and aldosterone levels are increased [3].

BS closely mimics the effects of chronic ingestion of a loop diuretic. Defects in the transport proteins of the thick ascending limb of $\mathrm{LOH}$ lead to loss of luminal-positive electrical transport potential which drives the paracellular reabsorption of sodium, calcium, and magnesium. It leads to loss of sodium, chloride, calcium, and magnesium in urine. Loss of sodium and chloride along with water with volume contraction lead to activation of rennin-angiotensin-aldosterone (RAA) pathway [4].

BS can occur due to various genetic defects leading to reduced activity of one of the several electron transporters in the thick ascending limb of LOH. Five main genetic defects are described. Defective function of the $\mathrm{Na}-\mathrm{K}-2 \mathrm{Cl}$ cotransporter in the luminal membrane [5], the luminal potassium channel [6], and the basolateral chloride channel [7] are the causes of BS types I, II, and III, respectively. Type IV BS is associated with sensorineural deafness due to reduced activity of both $\mathrm{ClC}-\mathrm{Ka}$ and $\mathrm{ClC}-\mathrm{Kb}$ transporters [8]. Defects in the calciumsensing receptor (CaSR) in the basolateral membrane of the thick ascending limb can impair sodium chloride transport and generate a mild Bartter phenotype called type $\mathrm{V}$ [9]. BS is commonly seen in the prenatal or neonatal period. Acquired BS is very rare with few case reports in the medical literature (Table 2). Chronic diuretic abuse with a loop diuretic is well known to cause BS-type phenotype [3]. Pulmonary tuberculosis [10] and antituberculous medications (capreomycin and viomycin) are known to cause a BS-like phenotype.

Table 2 Acquired causes of Bartter's syndrome

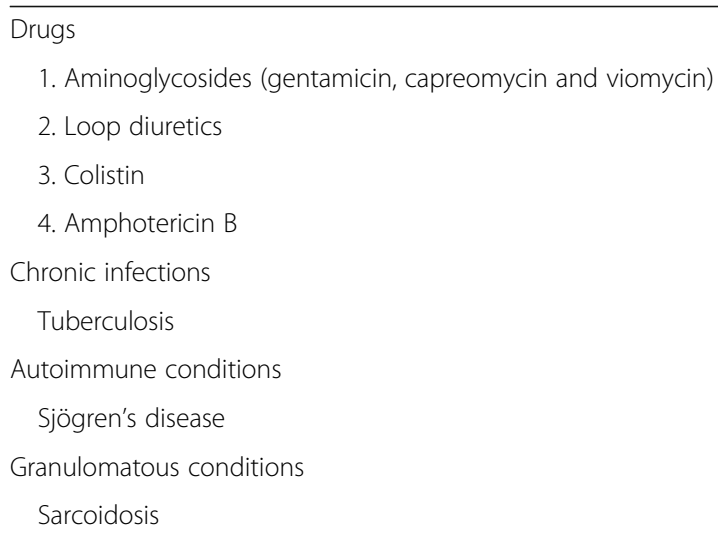


Several drugs are reported to produce a BS-like phenotype, including aminoglycosides [11, 12], colistin [13], and amphotericin B [14]. Acquired BS is reported in autoimmune conditions such as Sjögren's disease [15] and granulomatous conditions like sarcoidosis $[16,17]$.

Whether BS and diabetes mellitus are causally associated is unknown. In the literature a few case reports describe idiopathic BS-like phenotype in association with type 2 diabetes. Venkat et al. described patients with BS who displayed elevated insulin concentrations, with hyperplasia of the islets of Langerhans noted at autopsy [18]. Worsening of glycemic control following a diagnosis of late onset BS was described in another case report [19]. However, insulin secretion is decreased in hypokalemia [20]. Treatment with potassium supplements in BS improves glycemic control.

Our patient presented with worsening glycemic control with generalized weakness of the body with malaise. He was found to be severely hypokalemic with pottasium wasting in urine and metabolic alkalosis. We could not find any association with other conditions, including tuberculosis, sarcoidosis, or autoimmune conditions. He was not on long-term loop diuretics or other culprit drugs such as aminoglycoside and cisplatin. He had no past exposure to heavy metals. So a diagnosis of idiopathic acquired BS-like phenotype was made.

The mainstay of treatment in BS is correction of hypokalemia and alkalosis. Doses of potassium chloride supplementation should individually be titrated in accordance to the patient's needs and balanced by the renal loss [21]. Potassium-sparing agents such as spironolactone or triamterene would be an effective additive to supplementation since administered potassium is lost through the kidney in a short period of time. The most widely used group of medications in the treatment of classic BS is the prostaglandin synthetase inhibitors. Indomethacin, aspirin, and ibuprofen have all been tried and the best evidence comes from indomethacin [22]. As potassium wasting can be exaggerated by magnesium deficiency, there is a need to correct magnesium deficiency. In adults, the use of angiotensin-converting enzyme inhibitors (captopril, enalapril) has had conflicting results [23]. The use of selective and specific cyclooxygenase-2 (COX-2) inhibitors has been described as a successful treatment option in treating BS [24].

Our patient was initially treated with large intravenously administered doses of potassium chloride with orally administered potassium supplementation. Magnesium and calcium salts were supplemented. He was treated with large doses of spironolactone and indomethacin. With the treatment his potassium level increased to $3 \mathrm{mmol} / \mathrm{L}$, his glycemic control improved, and a marked improvement in weakness was noted.

\section{Conclusions}

Hypokalemia should be ruled out when patients present with generalized weakness of the body. Acquired BS should be considered in an adult with hypokalemia and hypochloremic metabolic alkalosis with increased urinary potassium loss.

\section{Availability of data and materials \\ Data sharing not applicable to this article as no datasets were generated or analyzed during the current study. \\ Authors' contributions \\ $C D, M P$, and SAMK examined, assessed, and were involved in the management of the patient. All authors collected data and analyzed. All authors read and approved the final manuscript.}

\section{Ethics approval and consent to participate}

Ethical approval was not obtained for the publication of this case report as this does not involve sharing of the personal details of the patient.

\section{Consent for publication}

Written informed consent was obtained from the patient for publication of this case report and any accompanying images. A copy of the written consent is available for review by the Editor-in-Chief of this journal.

\section{Competing interests}

The authors declare that they have no competing interests.

\section{Publisher's Note}

Springer Nature remains neutral with regard to jurisdictional claims in published maps and institutional affiliations.

Received: 24 November 2017 Accepted: 22 June 2018

Published online: 17 August 2018

\section{References}

1. Bartter FC, Pronove P, Gill JR, MacCardle RC. Hyperplasia of the juxtaglomerular complex with hyperaldosteronism and hypokalemic alkalosis. A new syndrome. Am J Med. 1962;33(6):811-28.

2. Ji W, Foo JN, O'Roak BJ, Zhao H, Larson MG, Simon DB, Newton-Cheh C, State MW, Levy D, Lifton RP. Rare independent mutations in renal salt handling genes contribute to blood pressure variation. Nat Genet. 2008;40(5):592.

3. Longo DL, Fauci AS, Kasper DL, Hauser SL, Jameson JL, Loscalzo S. Harrison's Principles of Internal Medicine, vol. 2. 18th ed. USA: The McGraw Hill Companies; 2012. p. 2360-1.

4. Gadwalkar SR, Murthy PR, Raghavendra, Nandini K, Deepa DV. Acquired Bartter-Like Phenotype. J Assoc Physicians India. 2015;63(9):78-9.

5. Simon DB, Karet FE, Hamdan JM, et al. Bartter's syndrome, hypokalaemic alkalosis with hypercalciuria, is caused by mutations in the $\mathrm{Na}-\mathrm{K}-2 \mathrm{Cl}$ cotransporter NKCC2. Nat Genet. 1996;13:183.

6. Simon DB, Karet FE, Rodriguez-Soriano J, et al. Genetic heterogeneity of Bartter's syndrome revealed by mutations in the K+ channel, ROMK. Nat Genet. 1996;14:152.

7. Simon DB, Bindra RS, Mansfield TA, et al. Mutations in the chloride channel gene, CLCNKB, cause Bartter's syndrome type III. Nat Genet. 1997;17:171.

8. Konrad M, Vollmer M, Lemmink HH, et al. Mutations in the chloride channel gene CLCNKB as a cause of classic Bartter syndrome. J Am Soc Nephrol. 2000;11:1449

9. Schlingmann KP, Konrad M, Jeck N, et al. Salt wasting and deafness resulting from mutations in two chloride channels. N Engl J Med. 2004;350:1314.

10. Stoian M, Chitac D, Bontas E, Dumitrescu AM, Stocia V. Bartter syndrome with pulmonary Tuberculosis a shortly outlook. Med J Clin Med. 2007;2:332-6.

11. Workeneh B, Sangsiraprabha W, Addison D, Longfield E. A novel case of persistent bartters-like syndrome associated with gentamycin exposure. Saudi J Kidney Dis Transpl. 2013;24:144-6.

12. Chrispal A, Boorugu H, Prabhakar AT, Moses V. Amikacin-induced type 5 Bartterlike syndrome with severe hypocalcemia. J Postgrad Med. 2009;55:208-10. 
13. Cakir U, Alan S, Zeybek C, Erdeve O, Atasay B, Yalcinkaya F, Arsan S. Acquired Bartter-Like Syndrome Associated with Colistin Use in a Preterm Infant. Ren Fail. 2013;35:3, 411-413. https://doi.org/10.3109/0886022X.2012.761084.

14. López Sastre JB, CotoCotallo GD, Fernández Colomer B. Neonatal invasive candidiasis: a prospective multicenter study of 118 cases. Am J Perinatol. 2003;20(3):153-63.

15. Miyata M, Takase Y, Kobayashi H, et al. Primary Sjogren's syndrome complicated by sarcoidosis. Intern Med. 1998;37:174-8.

16. Yu T-M, Lin S-H, Ya-Wen C, Wen M-C, Chen Y-H, Cheng C-H, Chen C-H, Chin C-S, Shu K-H. A syndrome resembling Bartter's syndrome in sarcoidosis. Nephrol Dial Transplant. 2009;24:667-9.

17. Muther RS, McCarron DA, Bennett WM. Granulomatous sarcoid nephritis: a cause of multiple renal tubular abnormalities. Clin Nephrol. 1980;14:190-7.

18. Venkat Raman G, Albano JD, Millar JG, Lee HA. Bartter's syndrome and diabetes mellitus. J Intern Med. 1990;228:525-31.

19. See T, Lee SP. Bartter's syndrome with type 2 diabetes mellitus. J Chin Med Assoc. 2009;72(2):88-90.

20. Zillich AJ, Garg J, Basu S, Bakris GL, Carter BL. Thiazide diuretics, potassium, and the development of diabetes: a quantitative review. Hypertension. 2006:48:219-24.

21. Rodríguez-Soriano J. Bartter and related syndromes; the puzzle is almost solved. PediatrNephrol. 1998;12:315-27.

22. Amirlak I, Dawson KP. Bartter syndrome: an overview. QJM. 2000;93(Issue 4): $207-21$

23. Hene RJ, Koomans HA, DorhoutMees EJ, Stople A, Verhoef GEG, Boer P. Correction of hypokalemia in Bartter's syndrome by enalapril. Am J Kidney. 1987;9:200-5.

24. Kleta R, Basoglu C, Kuwertz-Broking E. New treatment options for Bartter's syndrome. N Engl J Med. 2000;343:661-2.

Ready to submit your research? Choose BMC and benefit from:

- fast, convenient online submission

- thorough peer review by experienced researchers in your field

- rapid publication on acceptance

- support for research data, including large and complex data types

- gold Open Access which fosters wider collaboration and increased citations

- maximum visibility for your research: over $100 \mathrm{M}$ website views per year

At BMC, research is always in progress.

Learn more biomedcentral.com/submissions 